\title{
Pengaruh Media Pembelajaran dan Motivasi Berprestasi terhadap Keterampilan Membaca Puisi Bahasa Indonesia
}

\author{
Jaronah \\ Universitas Indraprasta PGRI \\ Jalan Nangka No. 58 C/TB. Simatupang, Tanjung Barat, Jakarta Selatan 12530 \\ jaronah.abdullah@gmail.com
}

\begin{abstract}
This study aims to find out about the Effect of Learning Media and Achievement Motivation on Indonesian Poetry Reading Skills in Central Jakarta State Middle School. The method of data collection in this study was to use the experimental method with proportional simple random sampling technique. To get research data, the author uses research instruments or data collection tools in the form of questionnaires and tests directly. Data processing is done by giving scoring on questionnaires based on a Likert scale, while the research method uses descriptive quantitative methods, aiming to describe or explain the testing of a theory measured by numbers and analyzed by statistical procedures. Conclusions from this study is that: 1) There is a significant effect of instructional media on Indonesian poetry reading skills in junior high school students in Central Jakarta City. This is evidenced by the acquisition of Sig. $=0,000<0,05$ and Fh $=18,033.2)$ There is a significant effect of achievement motivation on the ability to read Indonesian poetry in the Public Middle School students in Central Jakarta City. This is evidenced by the acquisition of Sig. = 0,000 $<0,05$ and $F h=44,531.3)$ There is a significant interaction effect on the medium of learning and achievement motivation on the ability to read Indonesian poetry in State Junior High School students in Central Jakarta City. This is evidenced by the acquisition of Sig. $=0.023<0.05$ and Fh $=5.475$.
\end{abstract}

Keywords: learning media, achievement motivation, Indonesian poetry reading ability.

\begin{abstract}
Abstrak
Penelitian ini bertujuan untuk mengetahui tentang Pengaruh Media Pembelajaran dan Motivasi Berprestasi Terhadap Keterampilan Membaca Puisi Bahasa Indonesia Siswa di Sekolah Menengah Pertama (SMP) Negeri Jakarta Pusat. Metode pengumpulan data dalam penelitian ini adalah menggunakan metode eksperimen dengan teknik Sampling acak sederhana proporsional. Untuk mendapatkan data penelitian, penulis menggunakan instrument penelitian atau alat pengumpul data berupa angket dan tes secara langsung. Pengolahan data dilakukan dengan pemberian skoring pada angket berdasarkan skala Likert, sedangkan metode penelitian menggunakan metode deskriptif kuantitatif, bertujuan untuk mendeskripsikan atau menjelaskan pengujian suatu teori yang diukur dengan bilangan-bilangan dan dianalisis dengan prosedur statistik. Kesimpulan dari penelitian ini adalah bahwa: 1) Terdapat pengaruh yang signifikan media pembelajaran terhadap keterampilan membaca puisi bahasa Indonesia siswa SMP Negeri di Kota Jakarta Pusat. Hal ini dibuktikan dengan perolehan Sig. $=0,000<0,05$ dan $\mathrm{Fh}=18,033$. 2) Terdapat pengaruh yang signifikan motivasi berprestasi terhadap kemampuan membaca puisi bahasa Indonesia siswa SMP Negeri di Kota Jakarta Pusat. Hal ini dibuktikan dengan perolehan Sig. $=0,000<0,05$ dan Fh =44,531. 3) Terdapat pengaruh interaksi yang signifikan media pembelajaran dan motivasi berprestasi terhadap kemampuan membaca puisi bahasa Indonesia siswa SMP Negeri di Kota Jakarta Pusat. Hal ini dibuktikan dengan perolehan Sig. $=0,023<0,05$ dan $\mathrm{Fh}=5,475$.
\end{abstract}

Kata Kunci: media pembelajaran, motivasi berprestasi, kemampuan membaca puisi bahasa Indonesia

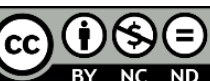

Creative Commons Attribution-NonCommercial-NoDerivatives 4.0 International License 


\section{PENDAHULUAN}

Peraturan Pemerintah Nomor 19 Tahun 2005 tentang Standar Nasional Pendidikan Bab 1 Pasal 1 Ayat 4 disebutkan bahwa "Standar Kompetensi Lulusan adalah kualifikasi kemampuan lulusan yang mencakup sikap, pengetahuan, dan keterampilan". Untuk mencapai lulusan yang berkualitas dalam berbagai hal, baik sikap, pengetahuan, maupun keterampilan. Maka disusunlah kurikulum pada setiap jenjang pendidikan yang terdiri dari beberapa mata pelajaran dan diharapkan dapat menunjang kompetensi lulusan.

Peningkatan kualitas proses dan hasil pembelajaran siswa di setiap jenjang pendidikan perlu diwujudkan agar diperoleh kualitas sumber daya manusia yang dapat menunjang pembangunan nasional di negara Indonesia. Dalam hal ini peran sebagai seorang guru sangat penting dan menentukan, sebab gurulah yang terlibat langsung dalam membina dan membimbing para siswa di sekolah melalui proses pembelajaran. Salah satu upaya untuk meningkatkan keaktifan siswa dalam proses pembelajaran adalah dengan penggunaan media pembelajaran.

Pemilihan media yang tepat pada waktu merencanakan pembelajaran akan mampu menambah gairah dan membangkitkan motivasi belajar siswa. Karena media sangatlah berperan penting dalam proses belajar mengajar di sekolah. Hamdani (dalam Arsyad, 2014:39) menggolongkan media menjadi: 1) Media Audio; 2) Media visual; 3) Media audio visual. Penggolongan tersebut akan mempermudah para guru atau praktisi lainnya dalam melakukan pemilihan media yang tepat untuk mencapai tujuan tertentu. Pemilihan media yang disesuaikan dengan tujuan, materi, serta kemampuan dan karakteristik pembelajaran akan sangat menunjang efisiensi dan efektivitas proses dan hasil pembelajaran.

Media pembelajaran Audiovisual adalah suatu media pembelajaran yang dapat kita dengar suaranya dan dapat kita lihat gambarnya secara langsung atau yang sering disebut dengan Video. Media ini sangat baik untuk merangsang motivasi dan minat belajar pada siswa dalam pembelajaran keterampilan membaca puisi, karena selain dapat menyajikan visual yang berupa latar belakang kepengarangan juga dapat menyajikan unsur audio yang berupa pembacaan puisi secara bersamaan. Dengan media audio-visual tersebut dapat memperjelas materi yang disampaikan dan pada akhirnya siswa terampil membaca puisi bahasa Indonesia.

Penggunaan media audio-visual tepat dipergunakan untuk meningkatkan kemampuan siswa dalam membaca puisi bahasa Indonesia. Penggunaan media ini penting dan sangat bermanfaat dalam proses belajar mengajar sebab media ini memiliki berbagai kelebihan. Salah satu kelebihannya adalah meningkatkan motivasi berprestasi pada siswa dalam belajar akan meningkat sebab media audiovisual pembelajaran lebih konkret atau nyata sehingga perhatian siswa terjaga.

Adapun cara guru mengajar adalah guru menjelaskan teori mengenai teknik membaca puisi kepada para siswa, setelah itu guru menjadi model untuk membaca puisi. Setelah praktik di depan para siswa, guru menunjuk beberapa siswa untuk mencoba membaca puisi dengan teknik-teknik yang sebelumnya telah dijelaskan oleh guru bidang studi. 
Menurut Djamarah dan Bahri (2002) "kata media berasal dari bahasa latin dan merupakan bentuk jamak dari kata "medium" yang secara harfiah berarti perantara atau pengantar". Dengan demikian, media adalah segala alat yang di gunakan oleh guru dalam proses belajar mengajar. Jadi, media dapat memudahkan seorang guru dalam mengajar, selain itu penggunaan media dapat membangkitkan motivasi belajar siswa. Sadiman, dalam Haling mengemukakan bahwa "kata "media" berasal dari bahasa latin yang secara harfiah berarti "perantara" atau pengantar". Kemudian menurut Hamalik dalam Haling (2007:94), mengemukakan bahwa yang dimaksud dengan media pembelajaran adalah, alat, metode, dan teknik yang di gunakan dalam rangka lebih mengefektifkan komunikasi dan interaksi antara pembelajar dan pembelajar dalam proses pembelajaran.

Beberapa pendapat ahli di atas maka dapat disimpulkan bahwa media adalah salah satu alternatif yang di gunakan oleh seorang guru dalam menyampaikan sebuah materi di depan kelas. Dengan menggunakan media seorang guru diharapkan bisa lebih mudah dalam menyampaikan materi dan siswa juga dapat menerima pelajaran dengan baik dan menyenangkan sehingga menimbulkan motivasi siswa untuk belajar dan berprestasi.

Menurut Hamdani (dalam Arsyad, 2014:39) Secara umum media dapat dibedakan menjadi tiga kelompok besar, yaitu sebagai berikut: 1) Media visual adalah media yang hanya dapat dilihat dengan menggunakan indera penglihatan yang biasanya digunakan untuk membantu guru dalam menjelaskan isi materi pelajaran, media yang menampilkan gambar diam. 2) Media audio adalah media yang mengandung pesan dalam bentuk auditif (hanya dapat didengar), yang dapat merangsang pikiran, perasaan, perhatian, kemauan para siswa mempelajari bahan ajar, media yang mengandalkan kemampuan suara. 3) Media audio-visual adalah kombinasi dari kedua media diatas (pandang dan dengar). Audio visual akan menjadikan penyajian bahan ajar kepada siswa semakin lengkap dan optimal. Selain itu, media ini dalam batas-batas tertentu dapat juga menggantikan peran guru. Sebab, penyajian materi bisa diganti oleh media, dab guru bisa beralih menjadi fasilitator belajar, yaitu memberikan kemudahan bagi para siswa untuk belajar. Contoh media audio visual, diantaranya program video atau televisi, video atau televisi instruksional, dan program slide suara (sound slide).

Motivasi yang dimaksud dalam penelitian ini adalah motivasi berprestasi. Dengan dipahaminya motif atau motivasi pada diri seseorang, bila dikaitkan dengan prestasi akan mempunyai pengertian tersendiri dan lebih khusus menggambarkan spesifikasi tentang dorongan atau kebutuhan akan gambaran berprestasi yang bervariasi pada diri seseorang. J.P Chaplin dalam Suryabrata (2013), motivasi berprestasi diartikan sebagai: 1) Kecenderungan untuk mencapai sukses atau memperoleh apa yang menjadi tujuan akhir yang dikehendaki. 2) Keterlibatan diri seseorang terhadap suatu tugas. 3) Harapan untuk berhasil dalam suatu tugas yang diberikan. 4) Dorongan untuk mengatasi rintangan-rintangan atau perjuangan melakukan pekerjaan-pekerjaan yang sulit secara cepat dan tepat.

Individu yang mempunyai motivasi berprestasi biasanya lebih menyukai tugas yang menuntut tanggung jawab. Hal ini berarti keberhasilan yang dicapai bukan karena bantuan orang lain atau karena faktor keberuntungan, melainkan karena hasil kerja keras dirinya sendiri. Selain itu individu juga mempunyai 
dorongan yang kuat untuk segera mengetahui hasil nyata dari tindakannya, karena hal itu dapat digunakan sebagai umpan balik. Selanjutnya dari hasil evaluasi tersebut individu dapat memperbaiki kekeliruannya dan mendorong untuk berprestasi lebih baik dengan menggunakan cara-cara baru.

Membaca puisi berarti mengarahkan segenap potensi dan kemampuan dalam memahami makna puisi dan mengekspresikannya dengan suara, ekspresi, dan gerakan yang sesuai dengan jiwa puisi tersebut. Pelafalan atau pengucapan, intonasi atau irama, mimik atau ekspresi, volume suara, kelancaran serta kecepatan, dan ketepatan gerakan di dalam penyampaian.

\section{METODE}

Metode yang digunakan dalam penelitian ini adalah penelitian deskriptif kuantitatif. Penelitian deskriptif adalah penelitian yang bertujuan memberikan gambaran yang jelas dan akurat tentang material atau fenomena yang sedang diselidiki (Arikunto, 2006). Dikatakan kuantitatif karena penyajian hasil penelitian dengan menggunakan angka-angka statistik, selain itu juga dikarenakan penelitian ini bertujuan untuk menggambarkan atau menjelaskan hubungan variabel bebas dan variabel terikat dalam bentuk angka yang akan diproses secara statistik dengan cara mencari informasi tentang gejala yang ada, didefinisikan dengan jelas tujuan yang akan dicapai, merencanakan cara pendekatannya, mengumpulkan data sebagai bahan untuk membuat laporan.

Dalam penelitian ini penulis ingin mengetahui atau mengukur keterkaitan mengenai pengaruh media pembelajaran (variabel X1) dan motivasi bberprestasi (X2) terhadap keterampilan membaca puisi bahasa Indonesia (Y) dimana X1 dan $\mathrm{X} 2$ merupakan variabel bebas pertama dan kedua serta Y Variabel terikat.

Penelitian ini dilakukan di tiga Sekolah Menengah Pertama (SMP) Negeri, yaitu siswa kelas VII di Kota Jakarta Pusat, Provinsi DKI Jakarta. dengan studi kasus siswa kelas VII dengan jumlah 600 siswa. Sampel dalam penelitian ini adalah siswa kelas VII Sekolah Menengah Pertama Negeri di Kota Jakarta Pusat yang berjumlah 60 siswa dalam satu sekolah.

Dalam penelitian ini, instrumen yang digunakan dalam pengumpulan data adalah kuesioner dan tes. Rancangan RPP digunakan dalam pengumpulan data variabel bebas pertama (A), yaitu media pembelajaran, untuk mengumpulkan data. Variabel bebas kedua (B), yaitu motivasi beprestasi yang digunakan dengan kuesioner, sedangkan tes digunakan untuk variabel terikat (Y).

Uji validitas dan relibilitas terhadap data yang masih mentah dilakukan untuk mengecek konsistensi alat ukur dan validitas dari masing-masing kuesioner. Untuk memperoleh hasil perhitungan yang akurat, proses perhitungan menggunakan komputer. Uji validitas empirik menggunakan teknik korelasi "product moment" dan instrumen layak (valid) selain itu reliabilitas menggunakan rumus koefisien Relibilitas Alpha Cronbach.

Analisis uji hipotesis penelitian menggunakan Anova dua arah. Analisis Varians (Anova) dua arah merupakan teknik analisis data penelitian dengan desain dua faktorial. Diketahui bahwa dalam penelitian ini terdapat dua variabel yang 
digunakan untuk dasar peninjauan untuk variabel terikat. Namun, sebelum pengujian hipotesis terlebih dahulu dilakukan uji persyaratan analisis, yaitu uji normalitas dan homogenitas. Uji normalitas bertujuan untuk mengetahui apakah data hasil pengumpulan terdistribusi normal atau tidak. Hal ini akan berpengaruh pada proses lanjutan analisis statistik. Uji normalitas dalam penelitian ini menggunakan analisis kolmogorov smirnov dalam program aplikasi komputer untuk statistik, yaitu menggunakan SPSS 20. Hasil perhitungan dan pengujian dengan SPSS 20 ditunjukkan oleh tabel test of normality pada kolom sig untuk pengujian teknik kolmogorov smirnov kriteria kenormalannya adalah jika nilai sig $>0,05$ maka data tersebut dikatakan berdistribusi normal. Uji homogen menggunakan uji lavene. Untuk pengujian ini kriteria homogenitas diperoleh jika nilai sig yang ada lebih dari 0,05 , jika memenuhi hal tersebut maka data tersebut homogen.

\section{HASIL DAN PEMBAHASAN}

Penelitian ini merupakan penelitian yang terdiri dari dua faktor bebas, yaitu faktor media pembelajaran (A) dan motivasi berprestasi (B). Masing-masing faktor terdiri dari sub faktor yang disebut level. Untuk media pembelajaran (A) ada dua, yaitu media pembelajaran Audiovisual $\left(\mathrm{A}_{1}\right)$ dan media pembelajaran Konvensional $\left(\mathrm{A}_{2}\right)$. Faktor kedua adalah motivasi berprestasi $(\mathrm{B})$ dengan dua level, yaitu: tinggi $\left(\mathrm{B}_{1}\right)$ dan rendah $\left(\mathrm{B}_{2}\right)$.

\section{Data Kemampuan Membaca Puisi Bahasa Indonesia Siswa yang} Menggunakan Media Pembelajaran Audiovisual (A1)

Data kemampuan membaca puisi bahasa Indonesia siswa yang menggunakan media pembelajaran Audiovisual diperoleh dari nilai tes responden yang menjadi sampel penelitian sebanyak 30 peserta didik. Nilai yang di peroleh adalah skor terendah 60 , skor tertinggi 95 , skor rata-rata sebesar 80,33 , median sebesar 82,50, modus sebesar 70 dan simpangan baku sebesar 10,981.

\section{Data Kemampuan Membaca Puisi Bahasa indonesia Siswa yang Menggunakan Media Pembelajaran Konvensional (A2)}

menggunakan media pembelajaran Konvensional diperoleh dari nilai tes responden yang menjadi sampel penelitian sebanyak 30 peserta didik. Nilai yang di peroleh adalah terendah 60 , skor tertinggi 90 , skor rata-rata sebesar 72,17, median sebesar 72,50, modus sebesar 60 dan simpangan baku sebesar 9,067.

\section{Data Kemampuan Membaca Puisi Bahasa Indonesia Siswa yang Memiliki Motivasi Berprestasi Tinggi $\left(B_{1}\right)$}

Data kemampuan membaca puisi bahasa Indonesia siswa yang memiliki motivasi berprestasi tinggi, diperoleh dari nilai tes responden yang menjadi sampel penelitian sebanyak 30 peserta didik. Nilai yang di peroleh adalah skor terendah 60 , skor tertinggi 95, skor rata-rata sebesar 82,67, median sebesar 85, modus sebesar 80 dan simpangan baku sebesar 9,535.

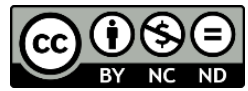


Data Kemampuan Membaca Puisi Bahasa Indonesia Siswa yang Memiliki Motivasi Berprestasi Rendah $\left(\mathbf{B}_{2}\right)$

Data kemampuan membaca puisi bahasa Indonesia siswa yang menggunakan motivasi rendah diperoleh dari nilai tes responden yang menjadi sampel penelitian sebanyak 30 peserta didik. Nilai yang di peroleh adalah skor terendah 60, skor tertinggi 90, skor rata-rata sebesar 69,83, median sebesar 70, modus sebesar 70 dan simpangan baku sebesar 7,822.

Data Kemampuan Membaca Puisi Bahasa Indonesia Siswa yang Menggunakan Media Pembelajaran Audiovisual dan Memiliki Motivasi Berprestasi Tinggi $\left(A_{1} B_{1}\right)$

Data kemampuan membaca puisi bahasa Indonesia siswa yang menggunakan media pembelajaran Audiovisual dan memiliki motivasi berprestasi tinggi diperoleh dari nilai tes responden yang menjadi sampel penelitian sebanyak 15 peserta didik. Nilai yang di peroleh adalah terendah 80, skor tertinggi 95, skor rata-rata sebesar 89,00, median sebesar 90,00, modus sebesar 85 dan simpangan baku sebesar 4,706.

Data Kemampuan Membaca Puisi Siswa bahasa Indonesia yang Menggunakan Media Pembelajaran Audiovisual dan Memiliki Motivasi Berprestasi Rendah $\left(\mathrm{A}_{1} \mathrm{~B}_{2}\right)$

Data kemampuan membaca puisi bahasa Indonesia siswa yang menggunakan media pembelajaran Audiovisual dan memiliki motivasi berprestasi rendah diperoleh dari nilai tes responden yang menjadi sampel penelitian sebanyak 15 peserta didik. Nilai yang di peroleh adalah skor terendah 60, skor tertinggi 90, skor rata-rata sebesar 71,67, median sebesar 70,00, modus sebesar 70 dan simpangan baku sebesar 8,165 .

Data Kemampuan Membaca Puisi Siswa yang Menggunakan Media Pembelajaran Konvensional dan Memiliki Motivasi Berprestasi Tinggi (A2B1)

Data kemampuan membaca puisi siswa yang menggunakan media pembelajaran Konvensional dan memiliki motivasi berprestasi tinggi diperoleh dari nilai tes responden yang menjadi sampel penelitian sebanyak 15 peserta didik. Nilai yang di peroleh adalah terendah 60 , skor tertinggi 90 , skor rata-rata sebesar 76,33, median sebesar 80,00, modus sebesar 80 dan simpangan baku sebesar 8,958.

Data Kemampuan Membaca Puisi Bahasa Indonesia Siswa yang Menggunakan Media Pembelajaran Konvensional dan Memiliki Motivasi Berprestasi Rendah $\left(\mathrm{A}_{2} \mathrm{~B}_{2}\right)$

Data kemampuan membaca puisi bahasa Indonesia siswa yang menggunakan media pembelajaran Konvensional dan memiliki motivasi berprestasi rendah diperoleh dari nilai tes responden yang menjadi sampel penelitian sebanyak 15 peserta didik. Nilai yang di peroleh adalah skor terendah 60 , skor tertinggi 80 , skor rata-rata sebesar 68,00, median sebesar 70,00 modus sebesar 60 dan simpangan baku sebesar 7,270. 
Data Rangkuman Kelompok $A_{1} B_{1}, A_{1} B_{1}, A_{1} B_{1}$, dan $A_{1} B_{1}$

Rangkuman data hasil penelitian sesuai dengan rancangan penelitian seperti tertera dalam tabel di bawah ini:

\section{Tabel 1. Rangkuman Statistic Deskriptif}

\begin{tabular}{|l|l|r|r|r|}
\hline \multicolumn{5}{|c|}{ Descriptive Statistics } \\
\hline \multirow{4}{*}{ Dependent Variable: Kemampuan Membaca Puisi Bahasa Indonesia Siswa } \\
\hline $\begin{array}{l}\text { Media } \\
\text { Pembelajaran }\end{array}$ & $\begin{array}{l}\text { Motivasi } \\
\text { Berprestasi }\end{array}$ & \multicolumn{1}{|c|}{ Mean } & Std. Deviation & N \\
\hline \multirow{4}{*}{ Audiovisual } & Tinggi & 89,00 & 4,706 & 15 \\
\cline { 2 - 5 } & Rendah & 71,67 & 8,165 & 15 \\
\cline { 2 - 5 } & Total & 80,33 & 10,981 & 30 \\
\hline \multirow{3}{*}{ Konvensional } & Tinggi & 76,33 & 8,958 & 15 \\
\cline { 2 - 5 } & Rendah & 68,00 & 7,270 & 15 \\
\cline { 2 - 5 } & Total & 72,17 & 9,067 & 30 \\
\hline & Tinggi & 82,67 & 9,535 & 30 \\
\cline { 2 - 5 } & Rendah & 69,83 & 7,822 & 30 \\
\cline { 2 - 5 } & Total & 76,25 & 10,800 & 60 \\
\hline
\end{tabular}

Berdasarkan data di atas, diperoleh data bahwa untuk kemampuan membaca puisi bahasa Indonesia siswa yang menggunakan media pembelajaran Audiovisual dan memiliki motivasi berprestasi tinggi terdiri dari 15 peserta didik menggunakan nilai rata-rata 89,00 dan standar deviasi 4,706. Untuk kemampuan membaca puisi siswa yang menggunakan media pembelajaran Audiovisual dan memiliki motivasi berprestasi rendah terdiri dari 15 peserta didik menggunakan nilai rata-rata 71,67 dan standar deviasi 8,165.

Untuk kemampuan membaca puisi bahasa Indonesia siswa yang menggunakan media pembelajaran Konvensional dan memiliki motivasi berprestasi tinggi terdiri dari 15 peserta didik menggunakan nilai rata-rata 76,33 dan standar deviasi 8,958. Untuk kemampuan membaca puisi bahasa Indonesia siswa yang menggunakan media pembelajaran Konvensional dan memiliki motivasi berprestasi rendah terdiri dari 15 peserta didik menggunakan nilai ratarata 68,00 dan standar deviasi 7,270.

\section{Uji Hipotesis}

Setelah dilakukan uji normalitas dan homogenitas dan hasilnya menunjukkan bahwa sampel penelitian berasal dari populasi distribusi normal dan varians sampel homogeny, maka pengujian hipotesis dengan menggunakan ANOVA dapat dilakukan.

Analisis terhadap data kemampuan membaca puisi bahasa Indonesia siswa dilakukan dengan menggunakan ANOVA dua arah yang pekerjaan rumahocess perhitungannya di bantu dengan pekerjaan rumahogram SPSS 20. Hasil uji ANOVA tersebut kemudian dilanjutkan dengan uji $\mathrm{F}$ untuk mengetahui signifikansi perbedaan diantara masing-masing kelompok secara signifikan (simple 
effect). Dengan kata lain, uji $\mathrm{F}$ digunakan dengan tujuan untuk melihat kelompok sampel mana yang lebih TINGGI kemampuan membaca puisi bahasa Indonesia siswa ditinjau dari media pembelajaran dan motivasi berprestasi.

Ringkasan hasil analisis data dengan menggunakan ANOVA dapat dilihat pada table berikut:

Tabel 2. Uji Hipotesis Penelitian

\begin{tabular}{|l|r|r|r|r|r|}
\hline \multicolumn{7}{|c|}{ Tests of Between-Subjects Effects } \\
\hline \multicolumn{7}{|c|}{ Dependent Variable: Kemampuan Membaca Puisi Bahasa Indonesia } \\
\hline Source & $\begin{array}{l}\text { Type III Sum of df } \\
\text { Squares }\end{array}$ & & Mean Square & F & Sig. \\
& $3774,583^{\mathrm{a}}$ & 3 & 1258,194 & 22,680 &, 000 \\
\hline Corrected Model & 348843,750 & 1 & 348843,750 & 6288,171 &, 000 \\
\hline Intercept & 1000,417 & 1 & 1000,417 & 18,033 &, 000 \\
\hline A & 2470,417 & 1 & 2470,417 & 44,531 &, 000 \\
\hline B & 303,750 & 1 & 303,750 & 5,475 &, 023 \\
\hline A $*$ B & 3106,667 & 56 & 55,476 & & \\
\hline Error & 355725,000 & 60 & & & \\
\hline Total & 68881,250 & 59 & & & \\
\hline Corrected Total & (Adjusted R Squared $=, 524)$ & & \\
\hline a. R Squared =,549 & & & \\
\hline
\end{tabular}

Berdasarkan data di atas, maka hipotesis penelitian yang diajukan dapat terjawab. Adapun penjelasan mengenai table di atas adalah sebagai berikut:

Hipotesis Pertama: terdapat pengaruh yang signifikan media pembelajaran terhadap kemampuan membaca puisi bahasa Indonesia siswa di SMP Negeri di Kota Jakarta Pusat.

Berdasarkan tabel 2 diperoleh hasil Anova dengan nilai Sig. $=0,000<0,05$ dan $\mathrm{Fh}=18,033$, maka hipotesis nol $(\mathrm{Ho})$ ditolak dan hipotesis riset $\left(\mathrm{H}_{1}\right)$ diterima. Hal ini menggunakan arti bahwa terdapat pengaruh yang signifikan media pembelajaran terhadap kemampuan membaca puisi bahasa Indonesia siswa SMP Negeri di Kota Jakarta Pusat, atau dengan kata lain, terdapat perbedaan kemampuan membaca puisi bahasa Indonesia siswa antara yang menggunakan media pembelajaran Audiovisual dengan yang menggunakan media pembelajaran Konvensional.

Hipotesis Kedua: terdapat pengaruh yang signifikan motivasi berprestasi terhadap kemampuan membaca puisi bahasa Indonesia siswa di SMP Negeri di Kota Jakarta Pusat.

Berdasarkan table 2 diperoleh hasil Anova dengan nilai Sig. $=0,000<0,05$ dan $\mathrm{Fh}=44,531$, maka hipotesis nol $(\mathrm{Ho})$ ditolak dan hipotesis riset $\left(\mathrm{H}_{1}\right)$ diterima. Hal ini menggunakan arti bahwa terdapat pengaruh yang signifikan motivasi berprestasi terhadap kemampuan membaca puisi bahasa Indonesia siswa di SMP Negeri di Kota Jakarta Pusat. Atau dengan kata lain, terdapat perbedaan kemampuan membaca puisi bahasa Indonesia siswa antara yang memiliki motivasi berprestasi tinggi dengan yang memiliki motivasi berprestasi rendah. 
Hipotesis Ketiga: terdapat pengaruh interaktif yang signifikan media pembelajaran dan motivasi berprestasi terhadap kemampuan membaca puisi bahasa Indonesia siswa di SMP Negeri di Kota Jakarta Pusat.

Berdasarkan table 2 diperoleh hasil Anova dengan nilai Sig. $=0,023$ $<0,05$ dan $\mathrm{Fh}=5,475$, maka hipotesis nol $(\mathrm{Ho})$ ditolak dan hipotesis riset $\left(\mathrm{H}_{1}\right)$ diterima. Hal ini menggunakan arti bahwa terdapat pengaruh interaktif yang signifikan media pembelajaran dan motivasi berprestasi terhadap kemampuan membaca puisi bahasa Indonesia siswa SMP Negeri di Kota Jakarta Pusat.

Sementara itu, nilai Adjusted R. Squared sebesar 0,549 menggunakan arti bahwa media pembelajaran dan motivasi berprestasi memberikan pengaruh sebesar $54,9 \%$ terhadap kemampuan membaca puisi bahasa Indonesia siswa SMP Negeri di Kota Jakarta Pusat.

\section{Uji Lanjut}

Untuk mengetahui sejauh mana pengaruh media pembelajaran dan motivasi berprestasi terhadap kemampuan membaca puisi bahasa Indonesia siswa, maka dilakukan uji lanjutan. Adapun uji lanjutan yang dipakai adalah uji Tukey.

Tabel 3. Uji Lanjut

\begin{tabular}{|c|c|c|c|c|c|c|}
\hline \multicolumn{7}{|c|}{ Multiple Comparisons } \\
\hline \multicolumn{7}{|c|}{$\begin{array}{l}\text { Dependent Variable: Kemampuan Membaca Puisi Bahasa Indonesia } \\
\text { Tukey HSD }\end{array}$} \\
\hline (I) & $(\mathrm{J})$ & Mean & Std. & Sig. & \multirow{2}{*}{$\begin{array}{l}95 \% \\
\text { Interval }\end{array}$} & Confidence \\
\hline Post Hoc & Post Hoc & Difference & Error & & & \\
\hline & & $(\mathrm{I}-\mathrm{J})$ & & & Lower & Upper \\
\hline & & & & & Bound & \\
\hline \multirow{3}{*}{ A1B 1} & A1B2 & 17,33 & 2,720 &, 000 & 10,13 & 24,53 \\
\hline & A2B1 & $12,67^{\prime \prime}$ & 2,720 & ,000 & 5,47 & 19,87 \\
\hline & A2B2 & $21,00^{3}$ & 2,720 & ,000 & 13,80 & 28,20 \\
\hline \multirow{3}{*}{$\mathrm{A} 1 \mathrm{~B} 2$} & A1B1 & $-17,33^{\prime \prime}$ & 2,720 & ,000 & $-24,53$ & $-10,13$ \\
\hline & $\mathrm{A} 2 \mathrm{~B} 1$ & $-4,67$ & 2,720 & ,325 & $-11,87$ & 2,53 \\
\hline & A2B2 & 3,67 & 2,720 & ,537 & $-3,53$ & 10,87 \\
\hline \multirow{3}{*}{ A2B1 } & A1B1 & $-12,67^{\prime \prime}$ & 2,720 & ,000 & $-19,87$ & $-5,47$ \\
\hline & A1B2 & 4,67 & 2,720 & ,325 & $-2,53$ & 11,87 \\
\hline & A2B2 & $8,33^{\prime \prime}$ & 2,720 & ,017 & 1,13 & 15,53 \\
\hline \multirow{3}{*}{$\mathrm{A} 2 \mathrm{~B} 2$} & A1B 1 & $-21,00$ & 2,720 & ,000 & $-28,20$ & $-13,80$ \\
\hline & A1B2 & $-3,67$ & 2,720 &, 537 & $-10,87$ & 3,53 \\
\hline & A2B1 & $-8,33^{\prime \prime}$ & 2,720 & ,017 & $-15,53$ & $-1,13$ \\
\hline
\end{tabular}

Berdasarkan uji lanjut di atas, dapat digambarkan bahwa pada kelompok 
A1B1 dan A1B2 terlihat bahwa Mean Difference sebesar 17,33 artinya selisih antara rata-rata kelompok A1B1 dan A1B2 sebesar 17,33. Nilai ini cukup besar dan dapat dibuktikan dengan nilai signifikansi $0,000<0,05$, atau dapat diartikan bahwa khusus untuk kelompok A1, terdapat perbedaan yang signifikan kemampuan membaca puisi bahasa Indonesia antara kelompok B1 dan B2. Pada kelompok A1B1 dan A2B1 terlihat bahwa Mean Difference sebesar 12,67, artinya selisih antara rata-rata kelompok A1B1 dan A2B1 sebesar 12,67. Nilai ini cukup besar dan dapat dibuktikan dengan nilai signifikansi $0,000<0,05$, atau dapat diartikan bahwa khusus untuk kelompok B1, terdapat perbedaan yang signifikan kemampuan membaca puisi bahasa Indonesia antara kelompok A1 dan A2. Pada kelompok A1B2 dan A2B2 terlihat bahwa Mean Difference sebesar 3,67, artinya selisih antara rata-rata kelompok A1B2 dan A2B2 sebesar 3,67. Nilai ini cukup kecil dan dapat dibuktikan dengan nilai signifikansi 0,537>0,05, atau dapat diartikan bahwa khusus untuk kelompok B2, terdapat perbedaan yang tidak signifikan kemampuan membaca puisi bahasa Indonesia antara kelompok A1 dan A2. Pada kelompok A2B1 dan A2B2 terlihat bahwa Mean Difference sebesar 8,33, artinya selisih antara rata-rata kelompok A2B1 dan A2B2 sebesar 8,33. Nilai ini cukup besar dan dapat dibuktikan dengan nilai signifikansi $0,017<0,05$, atau dapat diartikan bahwa khusus untuk kelompok A2, terdapat perbedaan yang signifikan kemampuan membaca puisi bahasa Indonesia antara kelompok B1 dan B2.

\section{SIMPULAN}

Berdasarkan hasil dan pembahasan, dapat disimpulkan bahwa tberdapat pengaruh interaktif yang signifikan media pembelajaran dan motivasi berprestasi terhadap kemampuan membaca puisi bahasa Indonesia siswa SMP Negeri di Kota Jakarta Pusat.

\section{DAFTAR PUSTAKA}

Arikunto, S. (2006). Prosedur Penelitian Suatu Pendekatan Praktik. Jakarta: Rineka Cipta

Arsyad, A. (2014). Media Pembelajaran. Cet-4. Jakarta: Raja Grafindo Persada. Djamarah., \& Bahri, S. (2002). Psikologi Belajar. Jakarta: Rineka Cipta Haling, A. (2007). Perencanaan Pembelajaran. Makassar: Badan penerbit UNM Suryabrata, S. (2013). Psikologi Pendidikan. Jakarta: PT. Raja Grafindo Persada 